\title{
CLS to Higher Education Administrator: The Right Navigational Skills
}

\author{
SUZANNE CAMPBELL, BARBARA Y LACOST
}

OBJECTIVES: To identify the experiences, training, and opportunities that directed and influenced the career paths of women clinical laboratory scientists that transitioned to higher education administrators.

METHODS: A multi-site case study design was selected for this qualitative research involving a purposive sample of eight research participants. Data collection was guided by ten open-ended questions in seven face-to-face and one telephone semi-formal interviews.

SETTINGS AND PARTICIPANTS: The purposive sample included women clinical laboratory scientists who held a current higher education administrative position at the dean's level, including associate and assistant dean positions, in a university setting. The participants were located in eight higher education institutions in Nebraska, Illinois, Ohio, Tennessee, Missouri, and Texas.

MAIN OUTCOMES MEASURES: Leadership skills/characteristics, professional development opportunities, mentoring experiences, opportunities for advancement.

The peer-reviewed Research and Reports Section seeks to publish reports of original research related to the clinical laboratory or one or more subspecialties, as well as information on important clinical laboratory-related topics such as technological, clinical, and experimental advances and innovations. Literature reviews are also included. Direct all inquiries to David L McGlasson MS, MLS, 59th Clinical Research Division/SGRL, 2200Berquist Dr., Bldg. 4430, Lackland AFB TX 78236-9908, david.mcglasson@lackland.af.mil

12 VOL 23, NO 1 WINTER 2010 CLINICAL LABORATORY SCIENCE
RESULTS: Possessing a doctoral degree, demonstrating competence and strong leadership skills, having a good role model and/or mentor, displaying the ability to see the big picture, and possessing exemplary communication skills were identified by this group of women as necessary requirements for obtaining and maintaining a position as a higher education administrator.

CONCLUSION: The participants in this study confirmed that by possessing a terminal degree and a defined skill set, they were able to obtain a higher education administrator position.

INDEX TERMS: career paths of women clinical laboratory scientists; women higher education administrators; women's leadership skills.

Clin Lab Sci 2010;23(1):12

Suzanne Campbell, PhD, MT(ASCP) is program coordinator and faculty, Medical Laboratory Technician Program, Seward County Community CollegelArea Technical School, Liberal, Kansas.

Barbara Y. LaCost, PhD, is an associate professor, College of Education and Human Services, University of Nebraska-Lincoln, Lincoln, Nebraska.

Address for correspondence: Suzanne Campbell, $P h D$, $M T(A S C P)$, program coordinator and faculty, Medical Laboratory Technician Program, Seward County Community CollegelArea Technical School, $520 \mathrm{~N}$. Washington, Liberal, KS 67901. (620) 417-1403, (620) 417-1449 (fax).suzanne.campbell@sccc.edu.

Acknowledgements: The authors would like to thank the women participants of this case study for sharing the experiences of their career paths as they transitioned 
from being clinical laboratory scientists to becoming higher education administrators.

The purpose for conducting this qualitative study was to investigate and document the career paths of women clinical laboratory scientists who have transitioned from the clinical setting to the higher education arena and held administrative positions at the dean's level, including assistant and associate dean positions. This research sought to identify the experiences, training, and opportunities that directed and influenced the career paths of these women.

Three major themes emerged from the data. They included: Getting to the Right Place at the Right Time, The Right Navigational Skills are Required, and The Right Place Comes with a Price. The Right Time Right Place theme described the three different career stops experienced by each of the participants. These findings were published in the Summer 2009 edition of Clinical Laboratory Science. ${ }^{1}$ The Right Navigational Skills theme was developed from two categories: don't wait for opportunity to knock and communication is the key. The findings that support this category are presented here. The Right Place Comes with a Price theme has been submitted for possible publication in a future edition of Clinical Laboratory Science.

\section{RESEARCH QUESTIONS}

To investigate the career paths of women clinical laboratory scientists who held higher education administrative positions, the following questions were considered.

1. What are the lived experiences of women higher education administrators with a background in clinical laboratory science during their career paths?

2. What skills, training, and/or professional development opportunities enabled these women to become successful higher education administrators when their initial academic area of study was clinical laboratory science?

3. What barriers and/or obstacles have these women experienced during their career paths as women clinical laboratory scientists who transitioned to higher education administration?

4. How has being a woman influenced their careers as higher education administrators?

This report focuses on the findings related to the research question that addressed the skills, training, and/or professional development opportunities that these women identified as contributing factors to obtaining a position as a higher education administrator.

\section{LITERATURE REVIEW}

Leadership has been studied since the time of the ancient Greeks. "Plato, Machiavelli, and Shakespeare offered images of leadership cast in the context of their times". In 1979, James McGregor Burns stated, "Leadership is one of the most observed and least understood phenomena on earth."

Modern day researchers such as Kouzes, Posner, Bass, Bennis, Stogdill, Bruce, and Avolio continue to research the topic of leadership. Much of the information resulting from the research has identified the delineation and overlap of management and leadership and the determination of a variety of leadership styles. However, numerous definitions of leadership and attempts to identify the qualities and skills one should possess to be an effective leader still remain.

The literature reviewed to support this study included studies of women's career paths in their pursuit of administrative positions in higher education and research findings that focused on the skills required to be successful administrators. Several themes emerged that contributed to the success of women as educational leaders: earning a doctorate degree, developing a mentoring relationship, participating in leadership development programs, and demonstrating high levels of skill and competence. ${ }^{3,4,5,6}$ Women who earned doctoral degrees were seen as highly credentialed and often were rated as more competent than those that did not possess doctoral degrees. The doctoral degree is essential for women to succeed in higher education. ${ }^{7}$ 
Development of a mentoring relationship with either a male or female mentor was identified as a successful strategy for women wanting to obtain educational leadership positions. ${ }^{5,7,8,9,10,11}$ These relationships helped develop self-confidence and self-esteem and provided internship opportunities. ${ }^{7}$

An additional strategy utilized by women in their quest to obtain leadership positions has been the participation in leadership development programs. The literature demonstrated the need for women in a variety of settings to experience leadership development opportunities. ${ }^{12,13,14,15}$ The American Council on Education Fellows program is a well-known, highly respected leadership development program for women in the higher education arena. ${ }^{13}$ Academic institutions also recognize the needs to develop women leaders from within their own ranks. The common solution is the formation of women's leadership programs that aim to provide workshops focusing on leadership competencies and administrative internships to hone the newly developed skills. ${ }^{14}$

The literature also indicated that women prefer the transformational style of leadership..$^{10,16,17}$ The components of successful transformational leadership are more in line with the socialization processes that guide the development of female values. ${ }^{16}$ Transformational leaders act as role models/mentors, communicate goals, display optimism, encourage innovation, and build relationships to achieve a common goal. ${ }^{17}$

Successful women leaders demonstrated high levels of skill in communication, problem solving, organizational savvy, team building, and instruction and curriculum. ${ }^{18,19}$ They utilized a team approach to formulate an atmosphere of openness, willingness to share power, and attentiveness to the needs of the institution.

Women need to be seen as leaders by presenting themselves as competent and task-oriented. They need to communicate intelligence and expertise. ${ }^{19}$ Women must establish the legitimacy of their authority without damaging their acceptability. They must demonstrate control of various situations and themselves. ${ }^{20}$

\section{METHODOLOGY}

This case study of women higher education administrators with a background in clinical laboratory science sought to illustrate topics using a descriptive mode of the common themes developed from the data. ${ }^{21}$ The semi-formal interviews were audio recorded for transcription and subsequent data collection, and analysis. The primary researcher reviewed the transcripts to ensure accuracy and precision. Any remaining need for clarification was sought from the participants.

After developing the initial categories, the researcher performed axial coding in which the data were assembled and reassembled. "22 "The process of relating categories to their subcategories, termed 'axial' because coding occurs around the axis of a category, linking categories at the level of properties and dimensions". ${ }^{23}$ The axial coding portion of the data analysis included looking for descriptive wording for the topics, turning them into categories, and determining relationships between the topics. The last phase of coding involved the writing of the story line. ${ }^{22}$

To provide credibility to the data, a variety of validation mechanisms was employed. For this study, member checks, rich-thick descriptions, and an external audit validated the data. ${ }^{24} \mathrm{~A}$ review of the participant curriculum vitas allowed for verification of the data indicated on the participant demographic information form. The member check allowed the participants to review the transcription documents for accuracy.

The use of rich-thick description of the data was used as a second validation method. Descriptive narratives play a large role in the reporting style of qualitative research. The rich descriptions were developed from the interview transcripts and the field notes. The intent of the narrative portion of the findings of the study was reported in such a manner as to allow the reader to be present in the setting and to "give the discussion an element of shared experiences". ${ }^{24}$ 
A third method of data validation was the use of an external audit performed by an experienced auditor not involved in the research project. The auditor employed a method of checking the recordings with the transcription documents and the conclusions determined by the researcher. ${ }^{24}$

\section{Participant Demographics}

All participants had a previous history of experience in the clinical laboratory. One participant had a formal degree in chemistry while the other women were formally trained clinical laboratory scientists. Position titles of this group of women included dean, assistant dean, and associate dean.

The majority of the participants were between 50 and 59 years of age. Five of the eight clinical laboratory scientists were married at the time of the study; seven had children. All of the participants had earned advanced degrees: two possessed masters degrees, three earned doctorates of philosophy, one was all but dissertation (ABD), one held a doctorate of arts, and one held an educational doctorate. One woman was an assistant professor, two were associate professors, and five women were full professors. All had a minimum of ten years experience as a faculty member.

Each of the eight participants was assigned a pseudonym and a university name that corresponded with a Greek letter. The selected pseudonyms included: Ann at Alpha University, Brianna at Beta University, Debra at Delta University, Gwen at Gamma University, Kelly at Kappa University, Lynn at Lambda University, Olive at Omega University, and Teresa at Theta University.

\section{RESULTS}

The Right Navigational Skills are Required theme was supported by two sub-categories: Don't Wait for Opportunity to Knock and Communication is the Key. These categories were supported by sixteen codes, and each was explored.

This select group of women higher education administrators provided a plethora of information when asked about their skills, training, and professional development opportunities. They indicated that communication, listening, interpersonal skills, and leadership skills were vital to their success. They further stated the need for strong leadership capabilities especially when they sought buy-in for the vision of the college and university. Surprisingly, one skill they mentioned was humor. Additional items included being committed to their position as well as the institution, and the opportunity to mentor others - especially other women.

\section{Don't Wait for Opportunity to Knock}

The first category that supports the right navigational skills is seeking and accepting a variety of opportunities. The data codes include seek and accept opportunity, seek professional development opportunities, being visible/visibility, seeing the big picture, having a mentor, learning at all levels, earning an advanced degree, and leadership training.

Seek and accept opportunity. The data revealed that these women obtained their administrative positions by seeking and accepting opportunities that broadened their knowledge of and visibility throughout the entire organization. They did not sequester themselves to their faculty duties and teaching responsibilities. Instead, they looked for opportunities for personal and professional growth. They volunteered for committee work and professional development opportunities. Ann advised women to take advantage of every opportunity to grow. She commented,

I know some people tell young faculty to focus on a particular research project or something, on a research area, and essentially to get narrower and narrower. Maybe that is where you should go if research is going to be your number one goal. But as a faculty person, I think getting lots of experiences is a little bit better. The opportunities to serve on different committees, to find out more about the organization, that's what you are going to need to know if you get in an administrative role. If you focus too much, you won't have any of those experiences. 
Debra advised,

I think that any project, any job that someone asks you to do, do it, volunteer for it. If there is anything special going on the college or university campus, volunteer. Get as much experience as you can in various areas.

Teresa believed that accepting opportunities should fit your career goals. She commented,

I will step forward and take what I consider reasonable risks and take as many opportunities as I can. There may have been opportunities there that I have not recognized as opportunities and maybe didn't pursue them where I could have. But generally speaking, I've been willing to make the next step into an opportunity. Unless...it was something that just did not fit with the career goals of where I was going.

\section{Seek professional development opportunities}

This group of women administrators was quick to point out that taking advantage of formal professional development opportunities was important. Examples of the various professional development experiences included: Toastmasters, an institutional cooperation committee, workshops conducted by state education coordinating boards, an American Council on Education workshop, and an ethnic leadership program and diversity workshops, along with formal education at the master's and doctoral level. To achieve a position as a higher education administrator, these participants indicated that their prior involvement with professional organizations and campus committees allowed them to demonstrate skills that are desirable for academic leaders.

\section{Being visible/visibility}

The participants reported that by being visible and having a reputation for possessing the desirable skills and traits of leaders, they were able to obtain their administrative positions. Brianna indicated,

The big issue was getting me known on campus. I was very well known in the college but really [needed] campus exposure and getting the campus perspective. So I [was] sent to every committee and every meeting known to man.

Ann shared, "Take advantage of things like being the [non-profit organization] co-chair. I would personally go visit everyone in our pathology department. I started to learn who the people were and just more about what was happening." They stayed visible on campus and sought the big picture.

\section{Seeing the big picture}

The opportunities that were sought or presented to these participants played a role in their ability to see the big picture. Several of the participants indicated that their roles in professional organizations and campus committees provided a mechanism for them to become known across campus. As a faculty member, department chair, and division chair, the view can be somewhat narrow and focused on specific areas. Brianna observed that in serving as an acting dean ". . . you really get a global view of campus and you don't get that kind of insider information as a faculty member." She noted a key item to her success as an administrator was the ability to "...see the big picture and to help other people see their role in it." The opportunity to serve on various high level committees allowed Brianna to grasp ". . . the sense of the feel of the campus and how things work." The transition to the administrative arena required these women to see the big picture, to see beyond their clinical laboratory science programs, and to fully comprehend the institutional mission and purpose.

\section{Having a mentor}

Mentoring was identified as a necessary component for success. This group of women had been mentored through various stages of their higher education careers. Four of the participants were mentored by men, while three were mentored by women. Most described their mentoring relationship as an informal arrangement. Their mentors encouraged them to seek learning opportunities at all levels of their careers. Debra, an adjunct faculty member, recalled that her mentor, the dean of instruction "took me under her wing. She 
preceded me. She left the position, then I applied and got it." Debra's relationship with her mentor was informal and the advice was very beneficial. "If she saw that I was getting ready to do something she didn't feel was good for my career, she would let me know." Lynn's mentoring relationship with her dean was grounded in his support for her advancement. "When the opportunity came to turn that program into a department and to take on a department chair position, he was there along the whole way saying 'you need to do that'." Lynn further commented, "This individual was important in influencing those types of decisions along the way and that made those decisions easier, more comfortable, more certain."

Although the women considered these experiences as forms of mentoring and referred to the individuals as mentors, the term that may more accurately describe this process and the individuals is modeling. The participants identified ideal leadership strategies in the administrators with which they worked and modeled those characteristics and practices.

\section{Learning at all levels}

Five of the eight participants indicated that to achieve their position as a higher education administrator, they had demonstrated the ability to take on a variety of projects and experiences. They were not afraid to explore unfamiliar areas and willingly accepted the opportunity to expand their knowledge of the institution where they were employed. Olive shared,

Maybe I was fortunate when I was at a small university. You had more of an overview - the coordinating board funding- there are a lot of chairs who still don't understand how higher education is funded. I think learning those things is key to understanding how the university operates. Really, just paying attention. I try to learn as much as I can about the other programs. When they're talking, I don't tune them out.

The main thrust of their responses indicated a need to volunteer, to be active on campus committees, to participate in professional development, and to "never say no" when asked to take a special assignment or project. These women indicated that they were often very busy with their existing responsibilities but were able to take on additional tasks and to do them well.

\section{Earning an advanced degree}

Early in their faculty careers, these women recognized that an advanced degree was a necessity. Lynn indicated, "I knew right away that if I would have wanted to stay in the university and ever get ingrained into the mainstream of academia, I needed that doctorate." Debra stated, "I should have gotten my $\mathrm{PhD}$ much earlier in my career. I think I would have been more open to some of the opportunities that came my way." Two participants completed course work toward earning their doctoral degrees but did not finish the program requirements. During the interviews, when asked about their career choices and if they would do anything different, both individuals indicated that they would obtain the terminal degree. They identified possessing a doctoral degree as "a must" in today's higher education administrative arena. All of the participants strongly urged young women striving for an administrative position in higher education to earn a doctoral degree. Kelly said, "It is something that you really, really, really need. Some of it is for credibility with other faculty." Additionally, Kelly stated, "It's [the $\mathrm{PhD}]$ a must in today's market."

\section{Leadership training}

The majority of these women shared their experiences related to learning to be a leader. For some, it was onthe-job training in a very informal manner. The participants described their mentoring relationships as informal opportunities to develop their leadership skills. For others, it was attending structured conferences and workshops to develop their leadership skills.

\section{Communication is the Key}

The second category that supports the right navigational skills is communication. The data related to this category includes communication skills, listening, being of service, teamwork, interpersonal skills, humor, commitment, and mentoring others. 


\section{Communication skills}

One participant described her necessary communication skills as formal public speaking and conducting meetings along with the informal communication with volunteers and faculty. The ability to communicate with faculty was one aspect that this participant thought was very important in her nomination for the associate dean position. Another participant emphasized that communication is key for all healthcare professionals to be effective. Gwen became very interested in communication skills. She commented, "I started doing a lot of lecturing about [the importance of communication]. I did a fair number of workshops talking about communication." Gwen admitted, "Not to say that I'm a good communicator, but I sure learned a lot about it, and I sure learned how to help people become better communicators, to frame their message both verbally and in writing." She was adamant that this skill assisted her as an educator and now as an administrator.

\section{Listening}

When the participants spoke of communication skills, they included the importance of listening. Four of the participants identified their ability to listen to their faculty and to hear their concerns as very important in their roles as administrators. Gwen said, "I think I listen well. My faculty have told me that I listen well." Kelly viewed listening as one aspect of her position as an administrator. She indicated "... there are things that you cannot resolve and cannot work through, but I think to listen is important ..." She further stated,

Maybe that's communication skills, but I see that as an important part of what I do. I have no problem working with people to resolve their issues or listening to what they see as an issue and seeing if there are ways to work that through.

The participants realized their ability to listen to the faculty and department chairs was key to their success.

\section{Being of service}

Three of the participants spoke of their administrative position as one of service. Brianna believed that communicating with people and convincing them that you can provide them with a service was vital to being a higher education administrator. She sensed a mentality of "us versus them" between faculty and department heads and the dean's office. Brianna "really tried to change the perception of the dean's office to a culture of service. We are here to facilitate, to help guide you." Kelly, in describing her position as one of service, stated, "I see administration in general as a service position. I don't know that everybody agrees with that." Teresa's vision of providing service to her people was to gather information and to make a decision. She described herself as "one that can make a decision and be firm" when required to, while hoping that she is always fair.

\section{Teamwork}

Another component of communication was the ability to form viable, effective teams. Debra shared that “... really being able to work with people to get them to work together and being able to go from $\mathrm{A}$ to $\mathrm{Z}$ on a project" is important in her role as assistant dean. Olive recognized that every "organization is made up of a variety of people and that everyone has different contributions to make." She noted that this "is a much better way to utilize people than to go against the grain." She added, “... putting those people in those areas where they have strengths, I think is very important."

\section{Interpersonal skills}

Trust, honesty, and respect were identified as necessary interpersonal skills. Being able to deal with people on an honest basis to build a level of trust was extremely important. Gwen described her interpersonal skills as "essentially how to work with people, how to listen to what they're saying and incorporate their ideas, how to respect what they're doing, and yet lead them to where they need to be."

\section{Humor}

Surprisingly, when asked about their leadership skills and characteristics, three of the participants identified humor as a skill. The humor described was not slapstick or being funny. It was more related to seeing things in 
perspective and not taking yourself or your position too seriously. An additional description of humor included having an openness and willingness to laugh and being willing to bring some lightness into somebody else's life.

\section{Commitment}

The participants were acutely aware of the level of commitment that was required to be successful at the administrative level. Gwen demonstrated her level of commitment by describing her relationship with her staff.

Some people you're just never going to change. You have to get them to focus on the things that are really important and let go of the other stuff. Sometimes it is hard, but I love what I do. If I moved up, I wouldn't be able to do the kind of things that I really love doing.

Teresa discussed her commitment to the job and the necessity of others considering a move to administration to develop an awareness of the position requirements.

They [future women administrators] need to consider whether they like that. It's very challenging but can be very exciting. If you don't like decision making, if you don't like conflict - not that any of us like conflict, but you may feel uncomfortable of trying to work through conflict. [It is like] being in the middle of the sandwich because you have people below you, you have people above you, and you have to advocate for both groups. They just really need to understand what they're getting into. And not go into it because 'I'm the best thing they've got'. Those are things they really need to avoid and know that they are going to make a commitment.

They talked about how hard they work, the stress related to the position, and the challenge of being a female in a male environment.

\section{Mentoring others}

During their career paths, the mentoring experiences of these women have varied. However, the majority of the participants have been involved in mentoring both students and staff. Brianna described experiences mentoring her graduate students. She commented,

One of my own students was all but dissertation, had a baby, and then disappeared. I tracked her down and got her to continue writing. She was almost there when she got pregnant again. I didn't hear from her. I [contacted] her and said 'You have to finish this for yourself.' She was getting no support from her mother or her husband. I dragged her through by her teeth. I hounded her.

Brianna also mentored her faculty. She used the same tactics with them as she had with the student. She indicated,

I dragged those others through it. I beat them up. I said, 'You have to finish.' You have to finish for a variety of reasons and I dragged at least four people through. I kept telling them 'You're going to need it later whether it's just self accomplishment or whether it's professional development. It's a life jacket. It's a life vest.'

They believed mentoring others was an important aspect of their roles as higher education administrators.

\section{CONCLUSION}

Time and time again these talented and productive women described the opportunities they sought out and accepted. They indicated that the skills, knowledge, and experience they gained from these opportunities assisted them in moving to the administrative level. They emphasized the need to be visible on campus, to do everything well, to possess the ability to see the big picture, to be mentored, and to seek the opportunity to learn at all levels.

By displaying the desired leadership and communication skills and competencies, these women were groomed for positions in higher education administration. During their ascension to administrative offices, they actively sought and accepted numerous opportunities to expand their knowledge and experiences. They promoted themselves by participation in campus committees so they could be more visible 
and to gain the "big picture" perspective of the institution. Learning the skills and gaining the education required for promotion were necessary tasks.

To be successful higher education administrators, these women emphasized the importance of communication skills, listening, interpersonal skills, and leadership skills. To gain buy-in for the vision of the college and university, having strong leadership capabilities was seen as a vital skill. The participants described their level of commitment to their positions and to their institutions. Although most of the discussion was of a serious nature, these women also stressed the importance of humor in the workplace.

Clin Lab Sci encourages readers to respond with thoughts, questions, or comments regarding this article. Email responses towestminsterpublishers@comcast.net. In the subject line, please type "CLIN LAB SCI 23(1) RE CAMPBELL". Selected responses will appear in the Dialogue and Discussion section in a future issue. Responses may be edited for length and clarity. We look forward to hearing from you.

\section{REFERENCES}

1. Campbell S, LaCost B. CLS to higher education administrator: the right place - right time. Clinical Laboratory Science 2009:22(3):185-92.

2. Shriberg A, Shriberg D, Lloyd C. Practicing leadership: principles and applications. New York: John Wiley and Sons, Inc; 2002.

3. Brown T. Female presidents of selected independent colleges: career paths, profiles, and experiences. Dissertation Abstracts International 2000;61(06A), 2205.

4. Murphy L. Women in vocational education leadership positions: their backgrounds and experiences. Journal of Vocational and Technical Education 1990;6:23-34.

5. Cook G. Mentoring relationships of women administrators in Mississippi's higher education. Dissertation Abstracts International 1999; 60(09A): 3209.

6. Majewski M. Hard-won tips for moving into administration. Women in Higher Education 2006;15(1):8-11.
7. Ballentine A. In her own words: what led pioneers to seek a community college presidency? Women in Higher Education 2001.

8. Evans G. By working together, we shall overcome. Women in Higher Education 2007; 16(2):1-2.

9. Searby L, Tripses J. Mentoring in a changing academy: why not? Women in Higher Education 2006;15(4):21.

10. Becker L. Why women excel as transformational campus leaders. Women in Higher Education 2006;15(2):1-3.

11. Larson V. Top 10 leadership tips for women on campus. Women in Higher Education 2005;14(12):1-2.

12. Bush E. Gender: a factor in leadership development programs. Corrections Today 2005;67(6):118-20.

13. McDaniel E. Senior leadership in higher education: an outcomes approach. Journal of Leadership \& Organizational Studies 2002;9(2):80-9.

14. Berryman-Fink C, Lemaster B, Nelson K. The women's leadership program: a case study. Liberal Education 2003;89(1):59-64.

15. Sampson S, Moore L. Is there a glass ceiling for women in development? Nonprofit Management and Leadership 2008;18(3):321-39.

16. Trinidad C, Normore A. Leadership and gender: a dangerous liaison? Leadership \& Organizational Development Journal 2005;26(7):574-90.

17. More women than men are supportive, inspiring leaders. Marketing to Women: Addressing Women and Women's Sensibilities 2003;16(9):6-8.

18. McGrath S. Here come the women. Educational Leadership: Journal of the Department of Supervision and Curriculum Development, N.E.A. 1992;48:62-5.

19. Gale S. Gender and leadership: the implications of small group research. The National Association of Women Deans, Administrators, and Counselors 1988;51:19-28.

20. Hall V. Dusting off the phoenix: gender and educational leadership revisited. Educational Management and Administration 1997; 25(3): 309-24.

21. Yin R. Case study research: design and methods. Thousand Oaks, CA: SAGE Publications, Inc; 2003.

22. Creswell J. Qualitative inquiry and research design: choosing among the five traditions. Thousand Oaks, CA: SAGE Publications, Inc; 1998.

23. Strauss A, Corbin J. Basics of qualitative research: techniques and procedures for developing grounded theory. Thousand Oaks, CA: SAGE Publications, Inc; 1998.

24. Creswell J. Research design: qualitative, quantitative, and mixed methods approaches. Thousand Oaks, CA: SAGE Publications, Inc; 2003. 